NARA INLET 1: A HOLOCENE SEQUENCE FROM THE WHITSUNDAY ISLANDS, CENTRAL QUEENSLAND COAST.

\title{
BRYCE BARKER
}

Antbropology \& Sociology

Uhiversity of Queensland

\section{INTRODUCTION}

This paper reports an archaeological excavation at Nara Inlet, Hook Island, one of the Whitsunday group off the central queensland coast. The site, Nara.. Inlet 1 , is a large rockshelter which returned a nonbasal 14C date of $8150 \pm 80 \mathrm{bp}$. The excavation forms part of a wider study investigating prehistoric island use by Aborigines of the Whitsunday region as well as archaeological change in the Holocene Period.

The Whitsunday group was first investigäted archaeologically by Rowland (1986), who carried out a general survey of Hook, Whitsunday, Lindeman and Shaw Islands. The survey results and recommendations for future research prompted my undertaking research in this region as part of a postgraduate degree. My particular interest concerned the explanation of perceived change in the Holocene archaeological record of Australia. Along with arid regions, island environments are particularly susceptible to climatic changes, especially those that influence changes in sea level, and water temperature. It was hoped that clear archaeological indicators of environmental change would be present in the archaeological record in the whitsunday area so that human reaction to that change (if any) might be investigated. An associated interest in social agents of change, focusing on debate stimulated by Lourandos (1980, 1983), ..was also a major feature of this research (for a discussion of this facet, see Barker 1990 in. press).

The major aim of this research was to determine if there was a pattern of late Holocene cultural change in terms of both site usage and site establishment and, if so, to outline possible, causal factors. To this end, a research design which entailed a regional survey and excavation of a number of sites, was developed in order to establish the date of initial occupation of the islands and.to find evidence of change. Secondly, the research attempted to isolate environmental parameters in the whitsunday region during the Holocene Period and to ascertain their relative influence on human resource exploitation, settlement pattern, and site location. Thirdly, the study sought to develop a methodology by which social explanations for archaeological change might be linked to the archaeological record. However, the purpose of this paper is to present baseline results, both ethnohistorical and archaeological. Discussion of theoretical issues and wider implications are outlined elsewhere (Barker 1990 in press). 
Today, Hook Island lies approximately $16 \mathrm{~km}$ from the mainland. It is the second largest island in the Cumberland group which consists of over 130 islands (commonly referred to as the whitsunday Islands) (Figure 1). The group is characterised by a pronounced drowned coastline, caused by Cainozoic block-faulting and the Holocene marine transgression. Thus, these scattered islands represent the peaks of a drowned landscape. The islands rise abruptly out of the sea and are largely devoid of beaches or accessible tidal fringes. Lying between the coast and the Cumberland Islands is the 28km-wide Hillsborough Channel, which imposes a significant barrier between the mainland and the islands.

The question of when. the seas inundated the Whitsunday region and attained their present levels has been the subject of considerable nesearch (Hopley 1974, 1975, 1983). The literature on sea level change during the Holocene is quite broad and often refers to world or panAustralian models (Gill \& Hopley 1972, Neumann 1972, Thom \& Chappell 1975, Chappell \& Thom 1977, Gill 1983, Flood 1983, Thom 1984). However, work relating to specific regions around Australia has shown that substantial regional variation has occurred in the Holocene. Hopley (1975,1983), whose work relates specifically to the central gueensland coast including the Bowen/Whitsunday area, has demonstrated that this region has a different sea level history than other parts of Australia. His (1983) data from reef and island systems around the Cumberland group indicate that at $10,000 \mathrm{BP}$ the sea.was $30 \mathrm{~m}$ below the present level, at $7,890 \mathrm{BP}{ }^{3}$ it was $21.8 \mathrm{~m}$ lower and at 6,500 BP it was at its present level. Hopley (1983) also notes there is no evidence of higher sea levels in the Whitsunday Islands after $6,500 \mathrm{BP}$.

Chappell and. Thom (1977) suggest that at 8,000 BP. sea "levels in the area 'would have been between $15 \mathrm{~m}^{\circ}$ and $21.8 \mathrm{~m}$ below present levels. If the mean is taken from this range, a level of $-18 \mathrm{~m}^{\text {is }}$ obtained. At that time Hook Island would have been part of the mainland, Hook and Whitsunday Islands would have been joined and the southern end of Whitsunday Island would have been connected to the mainland; forming a large peninsula. This means that the Nara Inlet 1 site would-have been no more than ca. $2.5 \mathrm{~km}$ from the coast at the time of its initial occupation.

$\therefore$

The geology of Hook'Island consists of minor pyroclastic flows and lavas belonging.to the Whitsunday Volcanics (Paine 1972).' The climate ig tropical with a summer wet season and a winter dry season. Vegetation varies on the islands as some have been farmed or continue to be altered through introduced animals" such as goats or through human "activity. Broadly speaking, rainforest species dominate, "interspersed with Hoop Pine and Acacia woodland; with an understorey of vines, and Xanthorea in cleared areas.

Extant faunal composition varies according to the relative impact of introduced species and European development. Hook'Island has wàlaby, rodents, goanna" and other reptiles and goats. Much of the terrestrial native fauna of Whitsunday island was killed off by introduced animals (Lamond 1960); however personal observation has established that wallabies, goannas and Melomys are still present todäy. "The iittoral fauna includes over a dozen species of edible shellfish including rockplatform, sand' and mud species, as well as crabs añd myriad fish. 


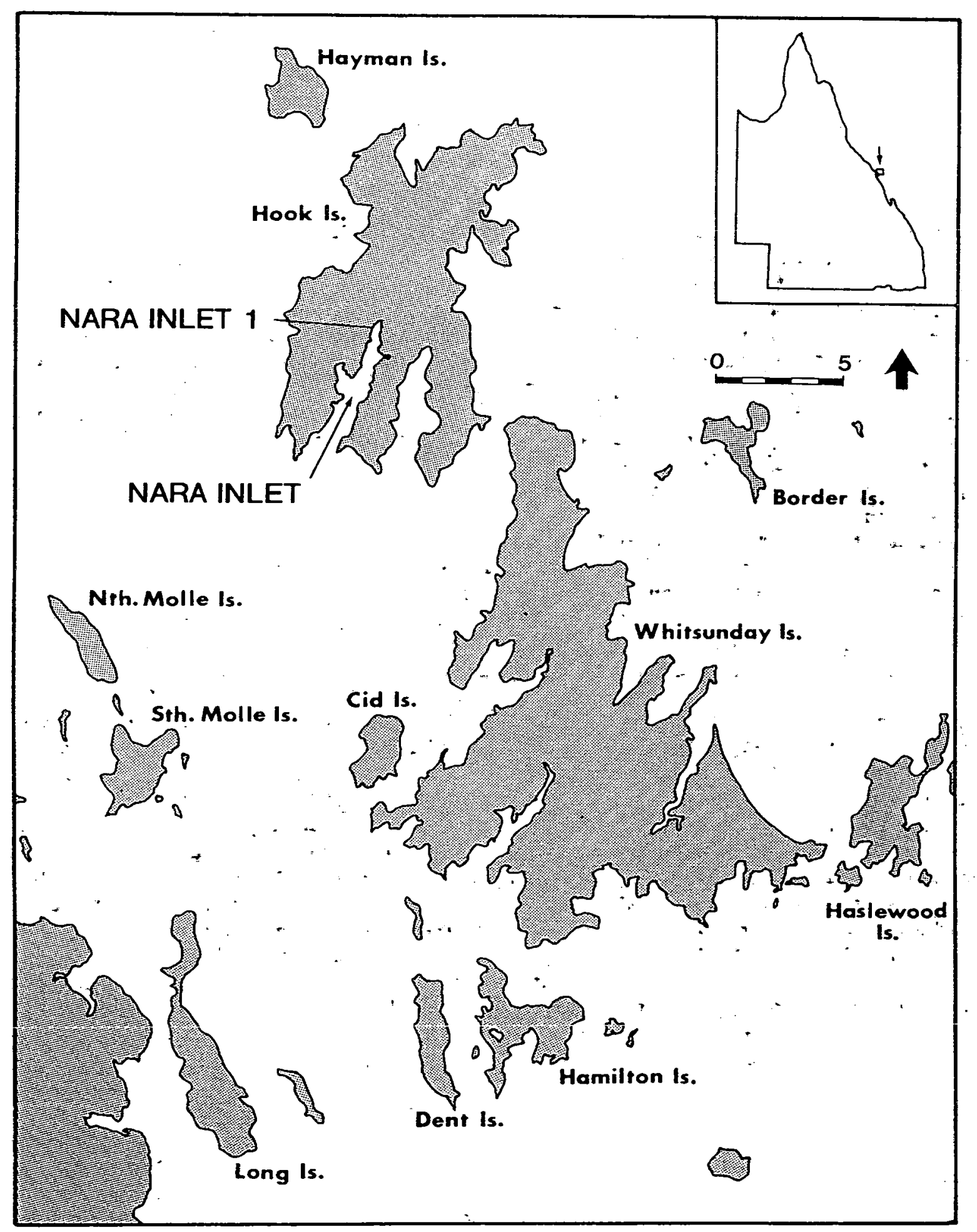

Figure 1. Map showing location of research area and Nara Inlet 1. 
Ethnohistorical records for the region are many but consist mainly of passages from observers on passing ships, or reports by mainland explorers. Thus, they tend to be fleeting observations rather than details concerning Aboriginal group names, population or social structure. Much of this information has been previously researched and published by Rowland (1986) and is only repeated here where considered relevant.

- From a variety of sources, a rough estimate of population sizes and assessment of social organisation may be made. Curr (1887) describes the island people $80 \mathrm{~km}$;north of Mackay as the Googaburra, one of 4 "tribes" around the Mackay area whose languages differed slightly from one another. Tindale (1974) calls the island people of the Cumberland group, including shute Harbour on the mainland, the Ngaro or Ngalangi.'He gives the term Googaburira as a "horde" grouping and as such they could be one of several Ngaro hordes or bands occupying the islands. According to Tindale the Ngaro, utilised a $500 \mathrm{~km}^{-2}$ area which included the islands of the: Cumberland Group and the adjacent mainland (Cape Conway). Curr (1887) gives the population of one of these tribes, the Tooginburra, whose country was just west of Broad sound, as 100 people, comprising some 40 men, 40 women and 20 children. Coppinger (1883) counted 40 or 50 people on. Dent Island in 1882 and statedi:his surprise at the large number of children. Percy, recorded as the "last of the whitsunday tribe", recounted, to Lamond (1960), a settler on South. Molle Island, that Whitsunday Island had a population of about 100 people: James Murrils, a sailor shipwrecked near Cape cleveland in 1852, 1ived 17 years with an Aboriginal group whose country extended: south of Cape cleveland down to the Bowen area (Gregory 1896): Murrils recounts that over a "thousand" people belonging to "10 different tribes" congregated for a ceremony in the dry season. Many of these early accounts do not give specific numbers but do refer to numerous "blacks" on the islands. This information is based on actual sightings of Aboriginal groups, smoke from far-away fires, and remains of recently abandoned camps (Flinders 1814, King 1827 , James n.d., Gregory 1896).

4. Later population estimates (mid-to-late $19 t \mathrm{~h}$ century), were representative of a population decimated by European disease, massacre, or displacement. Curr (1887) reports that during the decade following European occupation of the region, about half of the population was either killed by the Native Mounted Police "or perished from introduced loathsome diséases-before unknown". Large numbers of people died from a measlés epidemic in 1876 (Curr 1887). It is probable that diseases were introduced as "early as 1770 via-contact with the crews of numerous ships passing through the area (Flinders 1814, King 1827, stokes 1846, Beaglehole 1955). "In summary; many of the accounts relating to population estimates in the latter half of the 19 th century may be considered grossly, understated. As a corollary, it is infèrred from the many different accounts dating from the late 18th to the late 19th century that island populations in the Whitsundays were relatively. high.

One of the continuities of all ethnohistorical accounts relating to the Whitsunday region over a period of 130 years is reference to the use of canoes and a material culture associated with a maritime economy. While aware of an obvious maritime bias in the recorded material. (mostly from ships journals,_logs.or passengers diaries), there is sufficient other material to support the notion that the Ngaro pursued a predominantly marine-oriented subsistènce economy." Récords "make" it 
apparent that the people of the Whitsunday group were well adapted to water travel and thought nothing of regular long distance travel between islands. Three references to outrigger canoes, differences in material culture items, reference to large scale harvesting of root crops and the apparent separateness of island and mainland peoples illustrate some of the differences to be found in this area. References to material culture items are predominantly associated with a maritime economy (for a detailed account of the ethnohistory see Rowland 1986; Barker 1988).

The general picture extracted from ethnohistorical record for the Cumberland Island group is of an island people called the Ngaro who conservatively numbered 100 individuals. They moved freely between at least eight of the major islands in sturdy sea-going canoes. Although these people could be characterised as marine specialists, they had a seasonal round which included the hunting of Torres strait pigeon and the gathering of large quantities of plant foods. Stone for artefacts was quarried from South Molle Island and edge-ground axes were made from this material. Trade items such as baler shell water containers were traded to the mainland, while visits from northern peoples in outrigger canoes could have been responsible for different material culture items described. Much of the information relating to subsistence practices, settlement patterns and population, is archaeologically testable.

\section{THE ARCHAEOLOGY}

Serious archaeological research in the central Queensland coastal region was only initiated during the last decade or so, most of which was carried out by Rowland (1980, 1981, 1986). Rowland's is the only' work that has provided a chronology for the region. Other research includes a study of Wild Duck Island by Morwood (1982) and two studies of the Broadsound area (Neal.1985; Border (1985). Research specifically relating to the Whitsunday area includes a general survey in 1982 by Rowland (1986) and a report on Hook Island rock art by Walsh (1985).

In August 1988, impressed by the archaeological potential demonstrated by Rowland's work, I initiated preliminary field work. in the study area between Shaw Island in the south to Hayman Island in the north (thus not including the entire cumberland group). A non-random stratified survey strategy was employed which divided the study area into three units. Unit 1 (1008 sample) consisted of sites already recorded for the area (both ethnographically and archaeologically). Predictive site location models based on previous'work in the area were used for Unit 2 ( 508 sample). This consisted of combinations of inlets, sheltered bays, mangrove systems, permanent fresh water sources and areas of flat ground. Unit 3 (108 sample) included island.hinterland regions and areas of coastal fringe which exhibited none of the features of Unit 2 (for survey design detail see Barker 1988).

six sites in Nara. Inlet are listed in the archaeological site register of the Heritage Section, Queensland Department of Environment and Conservation section. All of them are rockshelters, three of which exhibited parietal art. In the course of the survey of Refuge Bay and Nara Inlet, two other rockshelters were located. These exhibited evidence of prehistoric human occupation. At Butterfly Bay another rockshelter was found to contain art; but the major art site is at Nara inlet. Walsh (1985) describes the art as non-figurative, consisting of freehand motifs with no evidence of engravings or conventional stencils. 
A considerable amount of, white and red painting is present, being particularly evident in net patterns, lines and other non-figurative motifs. According to Walsh (1985), net or grid motifs predominate in the Nara Inlet sites and generally bear a closer affinity to central Queensland net art than to any other Australian regional art body. It is apparent that this art is quite unlike the figurative art depicted on islands further to the north (e.g. Flinders group or Dunk Island).

Nara Inlet 1 lies directly opposite the major art site on the northern side. of the inlet. It is a large two-chambered rockshelter situated approximately $25 \mathrm{~m}$ above the high water mark. Excavations were carried out at this site.during two field seasons, the first in 1988 (a $1 \mathrm{~m} \times 50 \mathrm{~cm}$ pit), the second in 1989 (a $1 \mathrm{~m} \times 1 \mathrm{~m}$ pit) (Figure 2). The data presented here are largely from the former; however, preliminary results from the second season generally support the 1988 findings.

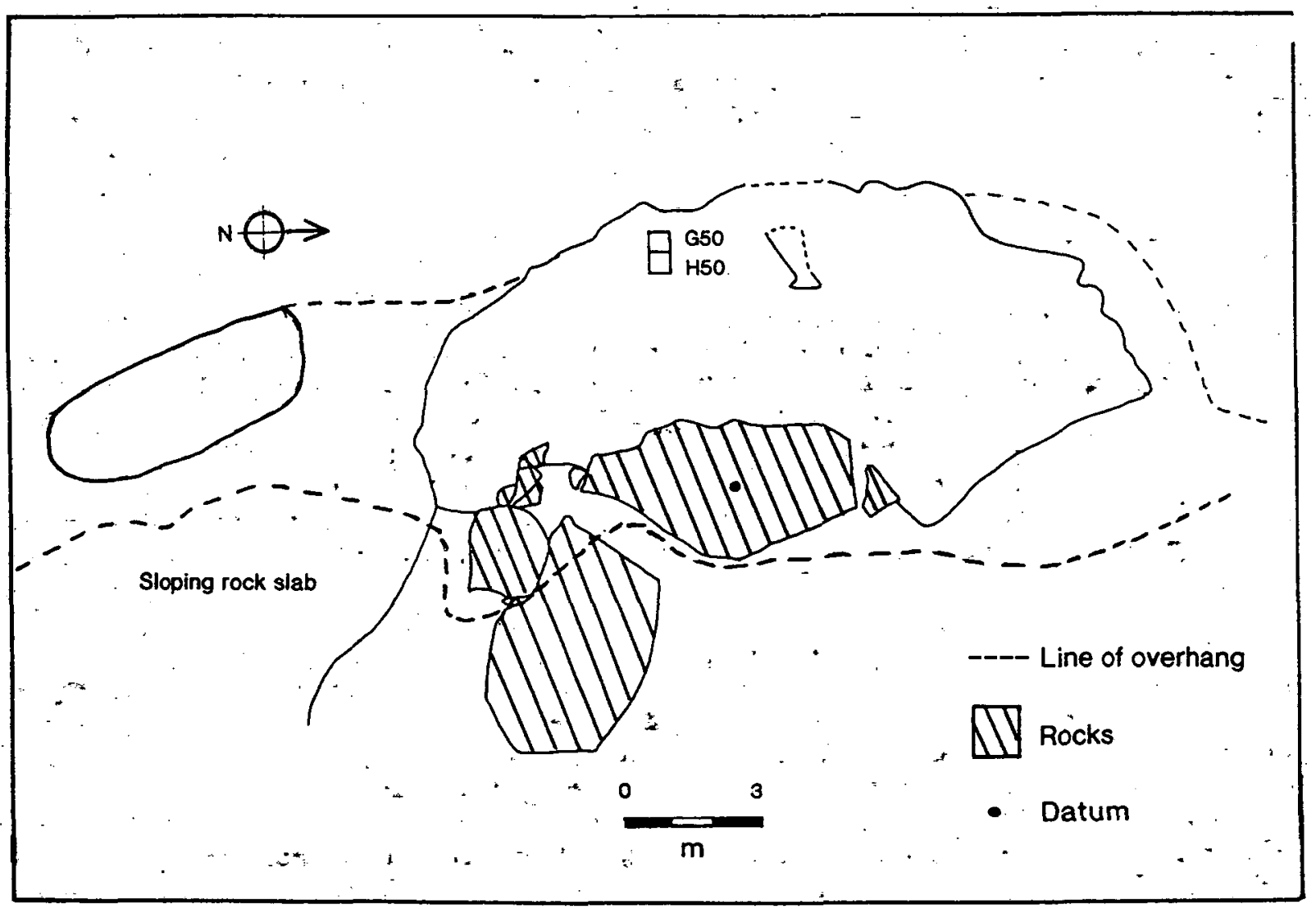

Figure 2. Site plan of Nara Inlet 1.

.

The 1988 excavation was located on the highest part of the floor deposit, $30 \mathrm{~cm}$ from the rear wall of the shelter. No stone artefacts were apparent on the surface but shell debris, fish bone, plant remains, and goat droppings. were evident. The pit was excavated to a depth of $130 \mathrm{~cm}$ before bedrock was encountered. Excavation employed the Johnson (1979) methodiof arbitrary "bucket" excavation units, each averaging $3 \mathrm{~cm}$ depth and following natural stratigraphic features where these occurred. Removed deposit was sieved through $3.0 \mathrm{~mm}$. wire mesh and bulk samples were taken from every. second excavation unit. In section, the pit deplayed four stratigraphic units as follows (see also Figure 3). 
Stratigraphic Unit 1 (SU1) consisted of extremely fine, loose gray sediment some $10 \mathrm{~cm}$ thick. This layer contained cultural material including paper bark, grass, nuts, seeds and netting. It also showed evidence of post-European disturbance; goat droppings were found in every excavation unit (XU) above XU5 $(8 \mathrm{~cm}$ depth). The absence of goat droppings below XU5 attested to the integrity of the lower layers.

Stratigraphic Unit 2 (SU2) was red-brown in colour and greasy in texture. The sediment was more compacted than in SU1. This unit was also characterised by numerous lenses of white ash, abundant charcoal and a high density of cultural material in the form of shellfish, fish, and plant remains.

Stratigraphic Unit $\underline{3}$ (SU3) began at a depth of $49 \mathrm{~cm}$ (in $\mathrm{XU} 30$ ) and was characterised by a colour change to brown, by less abundant charcoal, fewer ashy layers, and a decrease in shellfish remains relative to su2.

Stratigraphic Unit 4 (SU4) began at $95 \mathrm{~cm}$ depth (in XU46) and rested on bedrock: This unit was characterised by a green gravel of the same material as the rockshelter walls. Apart from $\mathrm{XU}^{\prime} \mathrm{s}, 46$ and 47 near the top, su4 was culturally sterile.

H50 EAST H50 SOUTH G50 SOUTH

$\mathrm{cm}$

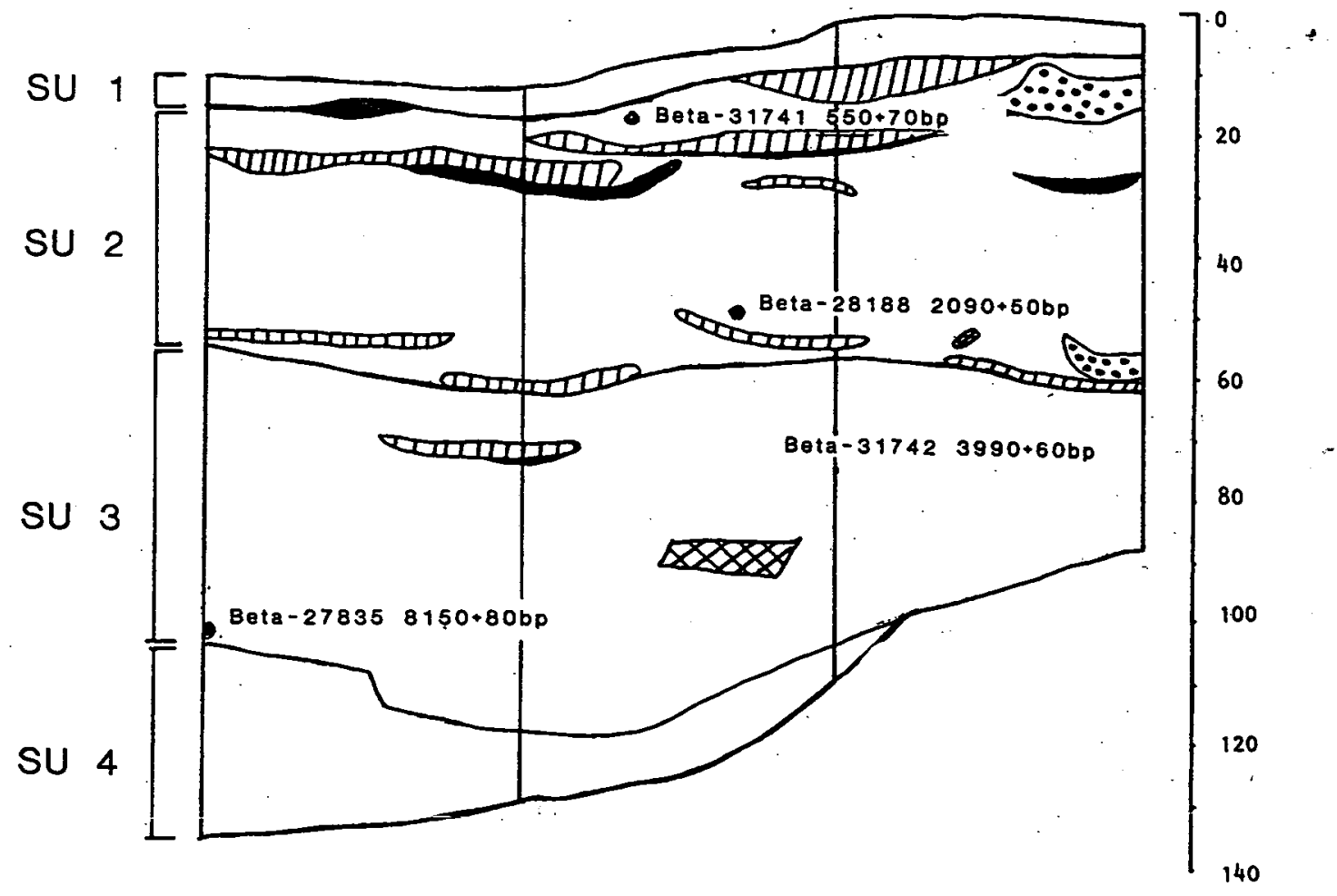

WHITE ASH

CHARCOAL

$\because \because$ SHELL ROCK

Figure 3. Stratigraphic section of Nara Inlet 1 . 
Four radiocarbon dates have been obtained for this site and are presented in Table 1 . below.

Table 1. Radiocarbon ages and calibrated dates for Nara Inlet 1.

\begin{tabular}{llllllr}
\hline LAB NUMBER & SITE NAME & XU & DEPTH & AGE bP & AGE BP* \\
\hline Beta 31741 & Nara Inlet 1 & 13 & $.15 \mathrm{~cm}$ & $550 \pm 70$ & 584 \\
Beta 28188 & Nara Inlet 1 & 28 & $46 \mathrm{~cm}$ & $2090 \pm 50$ & 2069 \\
Beta 31742 & Nara Inlet 1 & 35 & $66 \mathrm{~cm}$ & $3990 \pm 60$ & 4481 \\
Beta 27835 & Nara Inlet 1, & 45 & $96 \mathrm{~cm}$ & $8150 \pm 80$ & 8577 \\
\hline
\end{tabular}

* Calibrated ages employed CALIB program (stuiver and Reimer 1986)

The date of $8150 \pm 80$ (Beta, 27835) is non-basal, coming from near the bottom of the su3.. Thus, the site may be somewhat older. Beta 31742 came from near the top of SU3, while Beta 28188 and 31741 came from near the bottom and near the top of SU2 respectively.

A depth-age curve employing the calibrated ages of these samples is given in Figure 4 below. This shows an even gradient, of increase of deposit per unit age through time with a slightly higher increase after $2000 \mathrm{BP}$. It is important to note that the $20 \mathrm{~cm}$ gap between XU28 (2060 BP) and XU35 (4481 BP), representing a time span of 2412 years, is consistent with overall rates of deposition as well as discard rates of cultural material. This fact precludes the possibility of an hiatus between these datès.

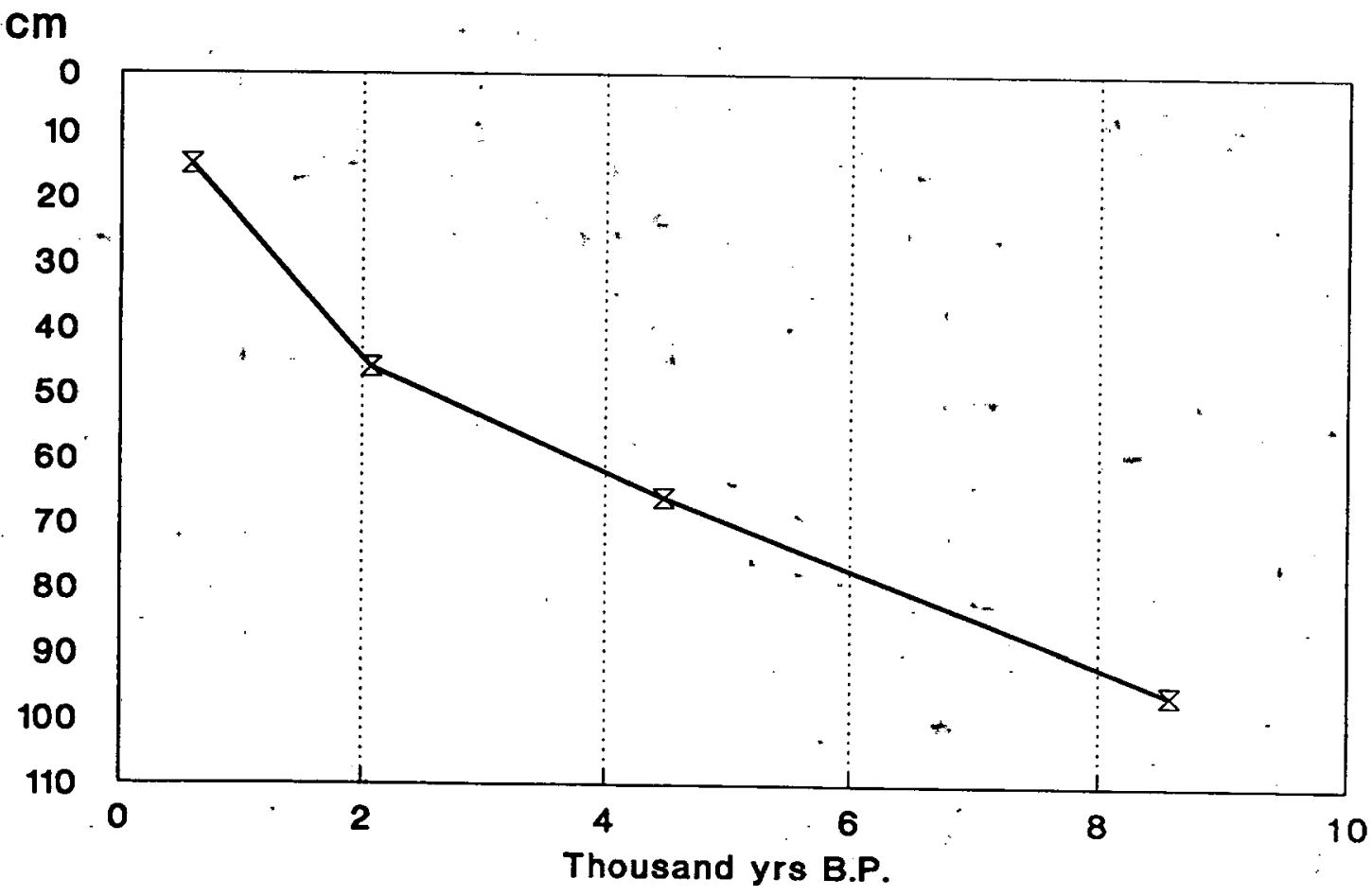

Pigure 4. Depth-Age Curve (calibrated) for Nara Inlet 1. 
Although a range of marine and terrestrial animal remains were recovered from the excavation, marine fauna dominated the faunal assemblage.

\section{Marine Fauna}

Ten species of shellfish were identified ( 5 bivalves, 4 gastropods, 1 Chiton), most of rock-platform origin. Most common were Nerites (Nerita undata), Top Shells (Monodonta labio), Chitons Acanthopleura sp. and Oysters (Saccostrea cucullata). Other taxa in descending order of abundance were Pearl shells (Pinctada sp.), Turban shells (Turbanidae), Isognomon ephisppium, Thaids sp., Hairy Mussels (Trichomya hirsuta and Asaphis violascens (Figures 5, 6 \& 7). Pinctada, Isognomon ephissppium and Asaphis violascens, which require sand or sandy-mud habitats, represent the only non rock-platform species.

The Nerites, Turbans and Top shells, although present in quite large numbers, are not considered to represent major food resources. Meat weight experiments carried out by the writer on Nerita undata demonstrated that for for every 10 Nerites sampled (from a total sample of 50 ) an average of only $2.0 \mathrm{~g}$ of meat was obtained. Although no such experiments were carried out for other species, previous experience argues that Oyster, Chiton, and Hairy Mussel would have provided the greatest returns of meat per individual.

Four fish taxa were identified including Parrotfish (Choerodon), Sweet Lip (Lethrinus, Red Emperor (Lutjanus) and Bream (Acanthropagus). All are common to Queensland coastal reef waters today (Table 2). All are large fish with maximum weights ranging from $22 \mathrm{~kg}$ (Lutjanus) to $4 \mathrm{~kg}$ (Acanthropaqus). All the fish identified fell within the upper enc of size ranges for their taxa. Although most can be caught with a hook and line or net, the size distribution argues for spearing (R. Mackay, Queensland Museum, pers com. 1989)." Choerodon, a fringing reef fish present in large numbers in the area today and the most common species in the site, is rarely caught with a hook and line (Grant 1985).

Table 2. Fish species MNI, Nara Inlet 1.

\begin{tabular}{|c|c|c|c|c|c|c|}
\hline $\mathbf{X U}$ & Lethrinus & Lutjanus & Acanthropaqus & Choerodor & TOTAL N & \\
\hline 3 & & & & 1 & 1 & : \\
\hline 4 & & & & 1. & 1 & \\
\hline 14 & & & . & 2. & 2 & \\
\hline 18 & & & & 1 & 1 & \\
\hline 20 & 1 & & & 1 & 2 & \\
\hline 26 & & 1 & & & 1 & \\
\hline 29 & & & & 1 & 1 & \\
\hline 32 & & & & 1 & 1 & \\
\hline 35 & & & & 1 & 1 & \\
\hline 39 & & & & 1 & 1 & \\
\hline 40 & 1 & & & & 1 & \\
\hline 41 & & & & 1 & 1 & \\
\hline 43 & & & & 1 & 1 & \\
\hline 45 & & & 1 & 1 & 2 & \\
\hline 46 & & & & 1 & 1 & \\
\hline Tot & 2 & 1 & 1 & 14 & 18 & \\
\hline
\end{tabular}


The marine assemblage also included turtle, (probably Chelonia mydas), small whale (Cetacea) mudcrab (Scylla serrata) and small rockdwelling crab. Turtle is represented in the site by artefacts of cut and ground pieces of cárapace. The whale. (in SU2) was identified as such by teeth but was unidentified to genus level. It is the smaller size range (120kg to $2000 \mathrm{~kg}$ ). Whales of this sort usually move in large schools and this individual may have been beached or perhaps harpooned. The mudcrab, scylla gerrata is a large mangrove/mud-dwelling crustacean attaining a weight in excess of $2.0 \mathrm{~kg}$ (Figure 8 ).

\section{Terrebtrial rauna}

The terrestrial component of the faunal asgemblage includes Wallaby (Macropus dorsalis), Pademelon (Thylogale stiqmatica), Possum (Tricoseurus - vulpecula), Bandicoot. (Isoodon sp.), rodents .(Rodentia), Python (Morelia sp.), Goanna (Varanid)" and small Lizard (Agamid) (Table 3). This faunal suite 18 typical of that present today on the mainland. Terrestrial animals do not appear to form a major subsistence component in the site; with the large Wallaby (up-to $20 \mathrm{~kg}$ )-representing the largest economic return. Although rodents are the most common animals in the site they are considered largely. non-economic because of their small size and the poselbility of other predators being responsible for their deposition (Table 3 ).

Table 3. Terrestrial fauna, marine maminal \& reptile. MNI

\begin{tabular}{|c|c|c|c|c|c|c|c|c|c|c|c|c|c|c|c|c|c|c|}
\hline$x U$ & & & CER & RRE & STR: & & & & AUI & & & & & & CHEF & & $\because$ & TOTAL \\
\hline$\therefore$ & TV & Md & $\mathbf{T}$ & {$[8$} & Io & $\mathbf{v}$ & & Mo & B & $\mathbf{A}$ & R & & . & $\mathrm{Cm}$ & $=\mathrm{C}$ & C. & . & $\ldots$ \\
\hline 1 & & . & & . & & 1 & 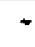 & $\bullet$ & 1 & 1 & . & & & $=$ & & & & 2 \\
\hline 2. & & & & & & & & & & 1 & $=1$ & & $\because$ & 1 & & & & 3 \\
\hline 3 & & & & & & & & & 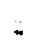 & & 1 & & & & . & & & 1 \\
\hline 10 & & & & & & & & $=$ & & 1 & $: 1$ &. & & & 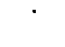 & & & 2 \\
\hline 17 & & & & & & & & & & $\therefore$ & 1 & & & & & & & 1 \\
\hline 18 & & & & & & $\because$ & & & & & 1 & & & & & & & 1 \\
\hline 19 & & & & & & & & & & & 1 & & & & & & & .1 \\
\hline 20 & & & & & & & & & & & 1 & & & 1 & & & & 2 \\
\hline 21 & & & & & & & & & & & 1 & $s$ & & • & & & & $1 *$ \\
\hline 24 & & 1 & & & & & & & & & & & & & & . & & 1 \\
\hline 29 & 1 - & & & - & & & & & & & $\because 1$ & 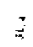 & $\therefore$ & & & $\cdot$ & & 2 \\
\hline 30 & & & : & & - & . & & & & & 1 & & & - & - & 1 & & 2 \\
\hline 33 & & & 1 & & & & & & & & & & & & & & & 1 \\
\hline 35 & . & & & $\because$ & & 1 & . & & & & 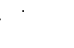 & & & & & & & 1 \\
\hline 36 & 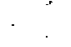 & & & & & & . & 1 & 1 & 1 & 4 & & & & & & ${ }^{\prime}$ & 3 \\
\hline 37 & • & & & & 1 & & & & & & 1 & & & & & & & 2 \\
\hline 38 & & & & $:$ & & . & & & & & 1 & & & & & & & 1 \\
\hline 40 & & & & . & & & & & & & 1 & & & & & . & & 1 \\
\hline 41 & & & & & & & & & & & 1 & & & & & & & 1 \\
\hline 42 & 1 & 1 & 1 & + & & & & & & & & & & & & & & 3 \\
\hline 44. & . & & & & 1 & & & & & & 1 & & & & & & & 2 \\
\hline 45 & & 2 & & & & 1 & & & . & & & & & & & & & 2 \\
\hline 46 & $:$ & & & 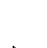 & & & . & r & & & $\mathbf{I}$ & & & & & . & & 1 \\
\hline & & '. & & & & & & & & & & & & & & & & $\therefore$ \\
\hline $\mathbf{T}$ & 2 & 4 & 2 & & 2 & 2 & - & 2 & 2 & 4 & 16 & & & 2 & & 1 & & 39 \\
\hline
\end{tabular}

KEY TV=Trichosurus vulpecula Md=Macropus dorsal1 $T \theta=$ Thylogale stiqmatica Io=Isoodon V:Varinad Mo=Morelia $B=B 1$ d $R=$ Rodent $A=A g a m i d a e ~ C m=$ Chelonia mydas $C=$ Cetacean 
A

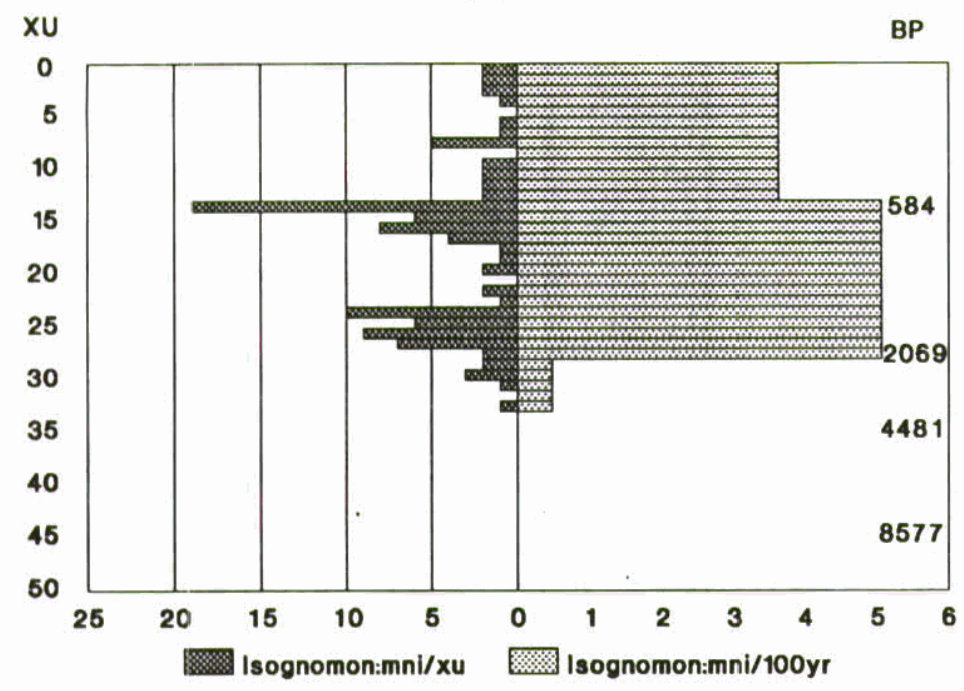

a

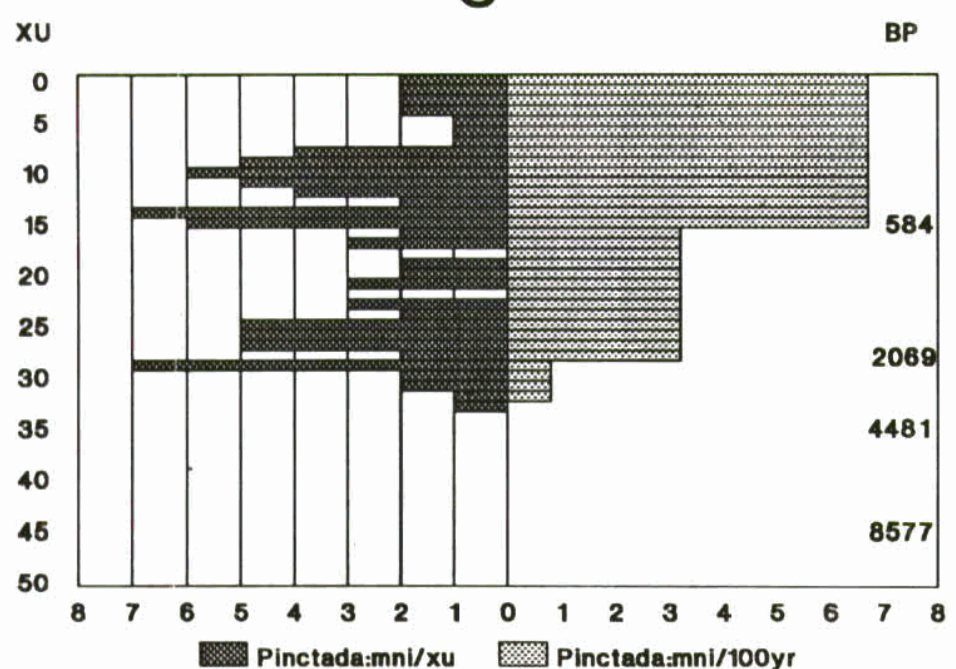

B

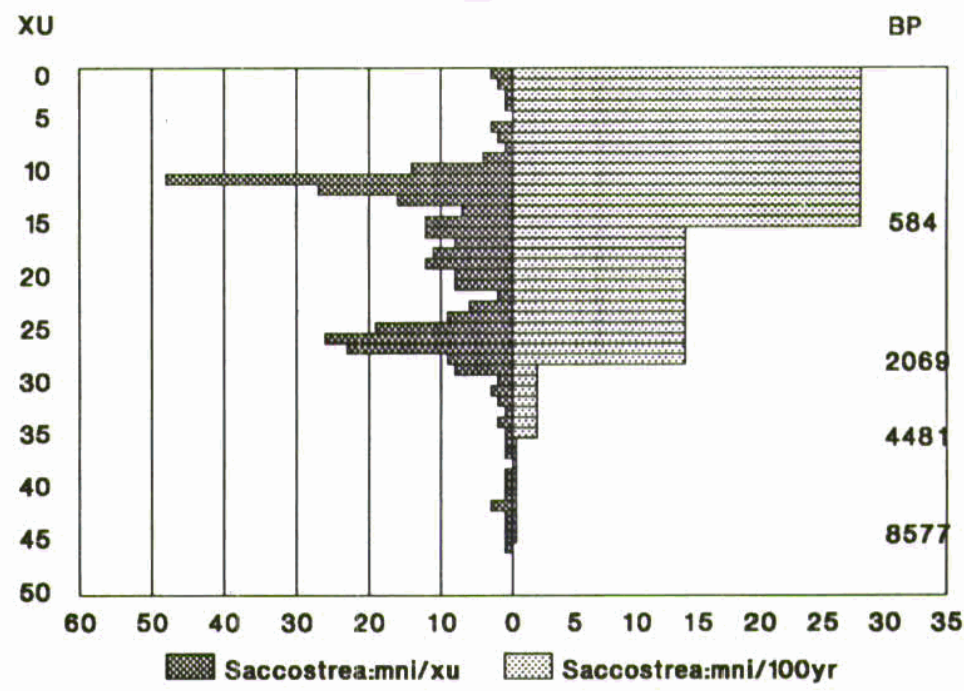

D

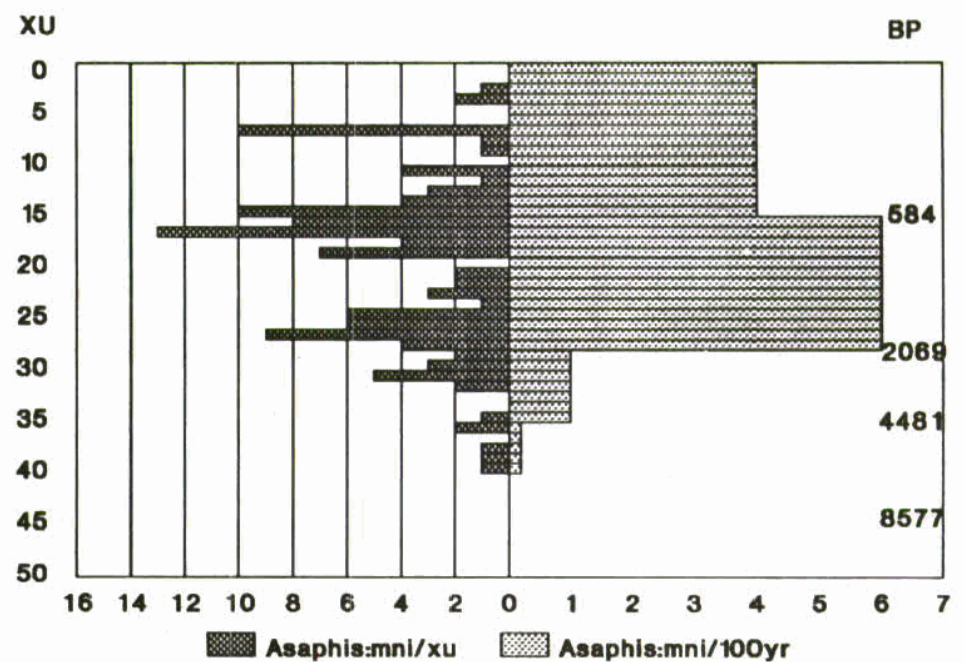

Figure 5. MNI per XU and discard per 100 years for: A. Isognomon, B.saccostrea culcullata, C.Pinctada, D.Asaphis. 
A

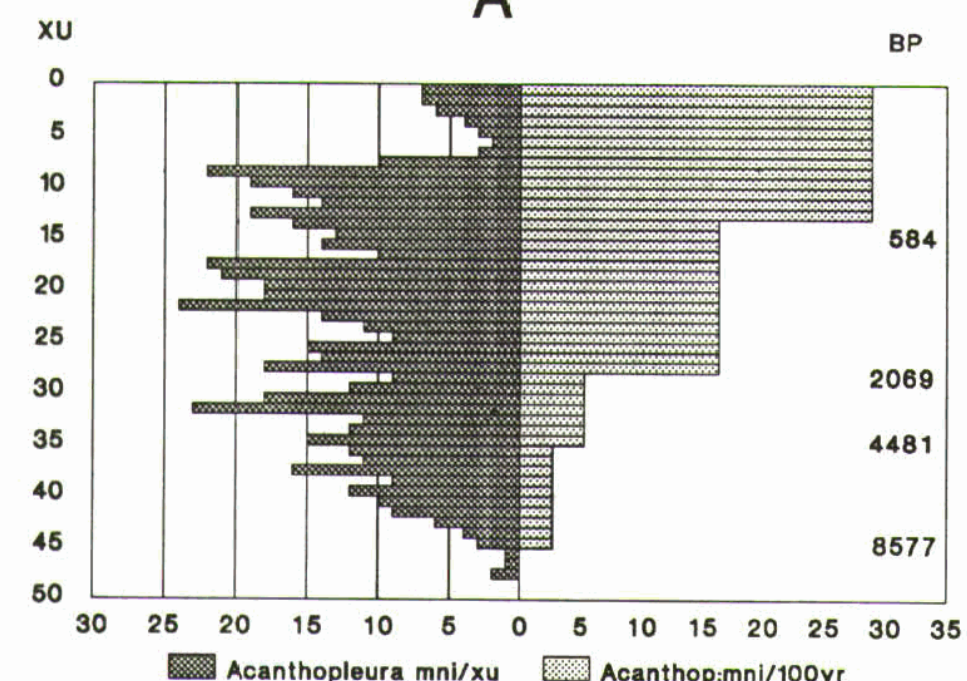

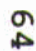

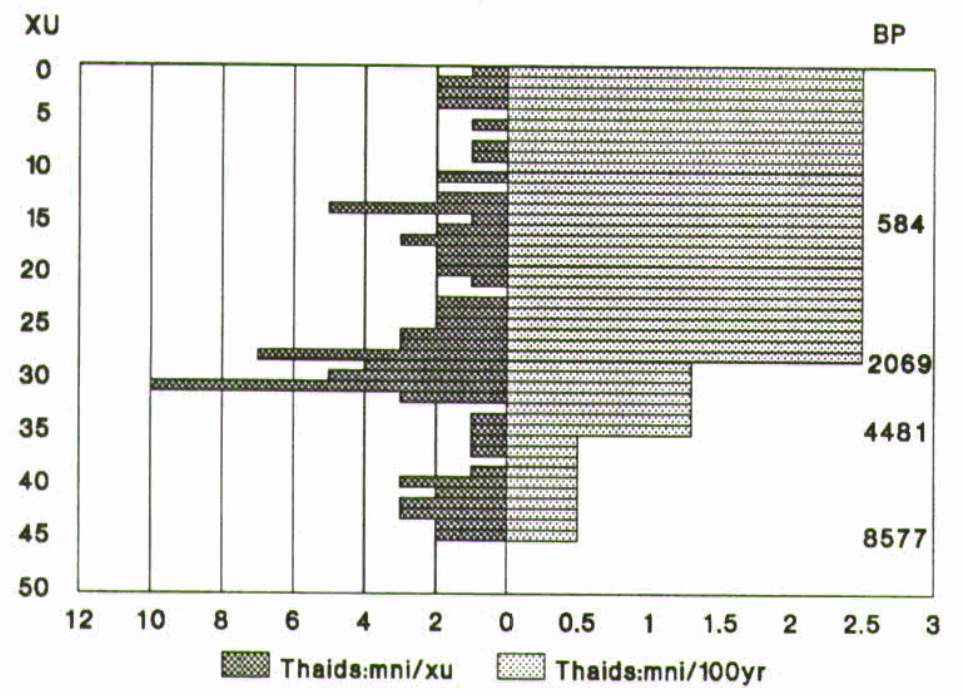

B

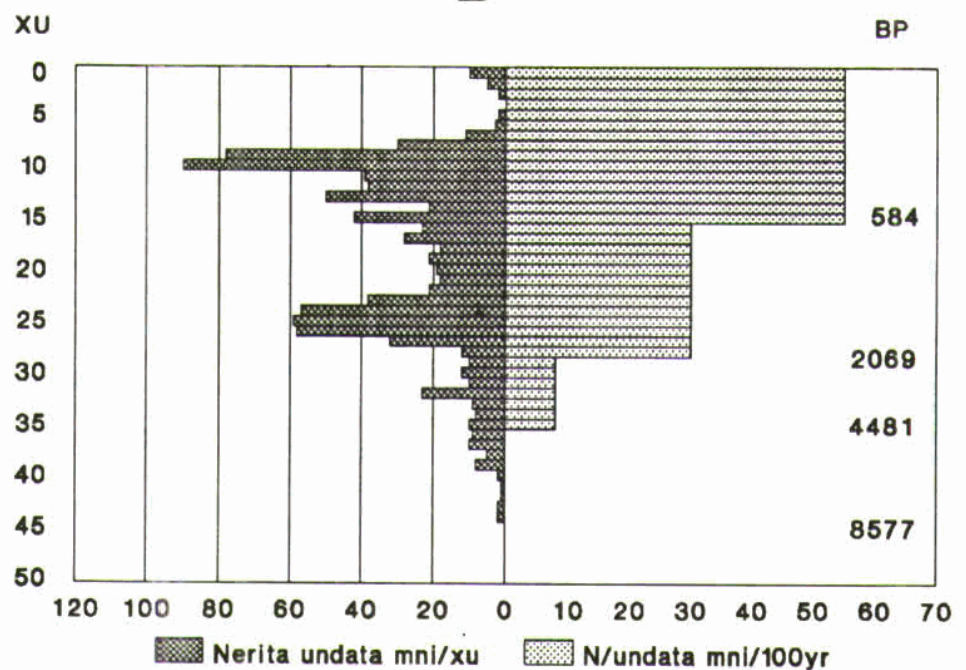

D

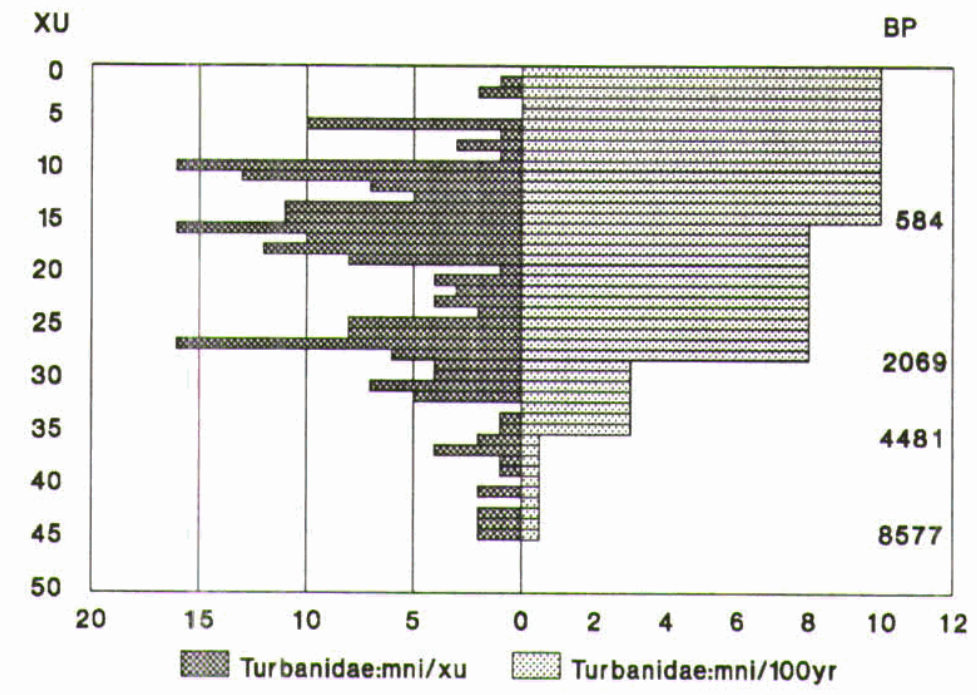

Figure 6. MNI per XU and discard per 100 years of: A.Acanthopleura, B.Nerita undata, C.Thaids, D. Turbanidae. 

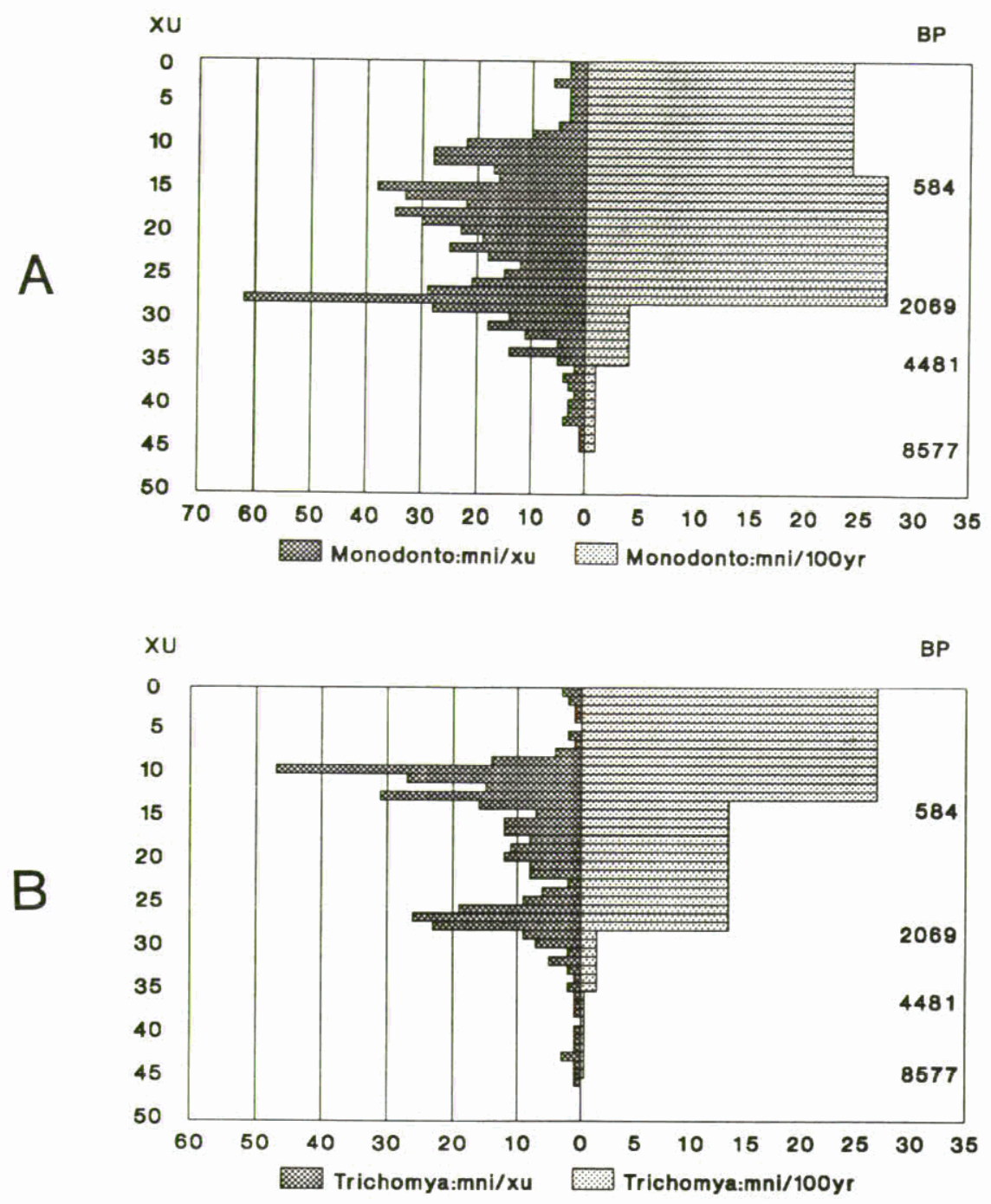

Figure 7. MNI per $X U$ and discard per 100 years of:

A. Monodonto labio, B.trichomya hirsuta.

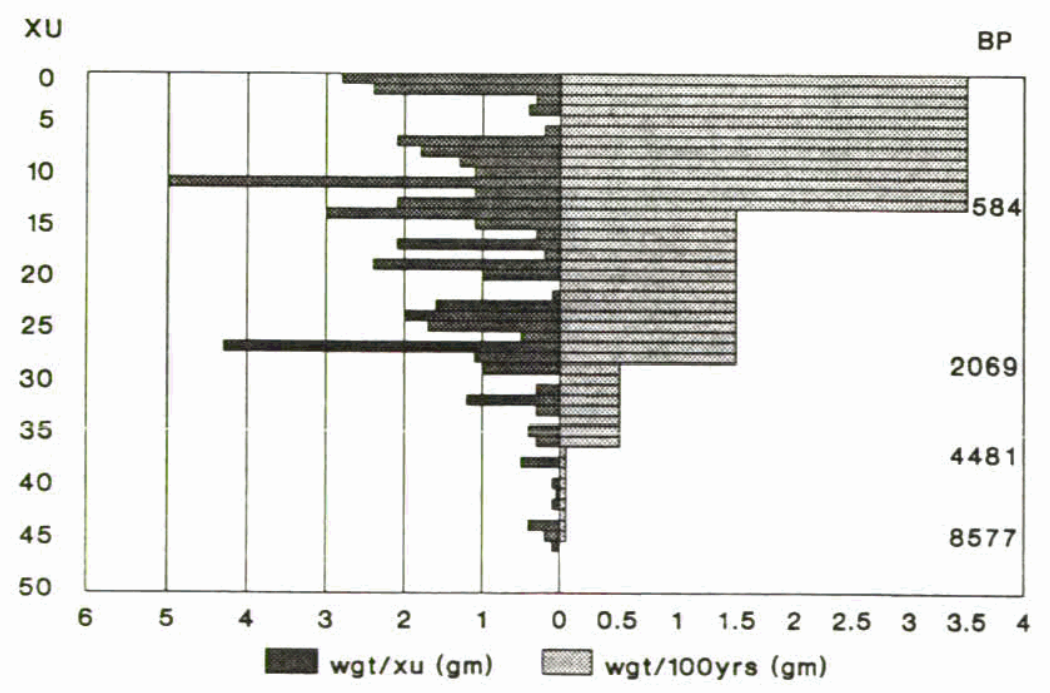

Figure 8. Weight (gm) per $\mathrm{XU}$ and weight $(\mathrm{gm})$ per 100 years for scylla serrata. 
Due to excellent preservation conditions in the deposit, plant remains were found both in abundance and in an identifiable state (Table 4). Plant taxa inferred to represent food remains included the Burdekin Plum, pleiogynium timorense (identified from seed), Cycas (nut shell), mangrove pod, Bruquiera gymnorhiza (flowers) and Cocky Apple, Planchonia careya (seeds). Both cycad nuts and mangrove pods require considerable processing before consumption. Bruquiera gymnorhiza contains a high proportion of tannin and must be extensively leached before eating Cycad contains highly toxic carcinogens and must also be leached (see Cribb and Cribb 1986).

A total of 65 seeds or shells of these four taxa were identified (most of them highly burnt). The presence of such an abundance of edible plant materials, a relatively rare occurrence in Australian archaeological sites, argues for their extensive use. All four plants are from tropical or semi-tropical habitats. Although the edible species only occurred in the upper stratigraphic units, it is relevant to point out that this would appear not to result from differential preservation, as plant material was present throughout the site; sticks, grass, leaves, bark (including paper bark) and seeds were retrieved from the lowest excavation units (Figure 9).

Table 4. Edible plant species, MNI for Nara Inlet 1

\begin{tabular}{|c|c|c|c|c|c|}
\hline \multirow[t]{2}{*}{$\mathrm{XU}$} & \multicolumn{3}{|c|}{ PLANT SPECIES } & \multirow[b]{2}{*}{$\frac{\text { Bruquiera }}{\text { gymnorhiza }}$} & \multirow[t]{2}{*}{ TOTAL } \\
\hline & $\begin{array}{l}\text { Pleiogynium } \\
\text { timorense }\end{array}$ & $\frac{\text { Planchonia }}{\text { careya }}$ & Cycas & & \\
\hline 1 & 1 & 4 & 1 & & 6 \\
\hline 2 & 3 & & & & 3 \\
\hline 3 & 1 & 1 & & & 2 \\
\hline 4 & 4 & & & & 4 \\
\hline 5 & 1 & 2 & 2 & 4 & 9 \\
\hline 6 & 1 & & 2 & 2 & 5 \\
\hline 7 & 2 & & & & 2 \\
\hline 8 & 3 & & & & 3 \\
\hline 9 & 1 & & & & 1 \\
\hline 10 & 1 & & 1 & 1 & 3 \\
\hline 11 & 7 & & 1 & & 8 \\
\hline 12 & 3 & & & & 3 \\
\hline 13 & 2 & & & & 2 \\
\hline 14 & 1 & & & & 1 \\
\hline 15 & 1 & & & & 1 \\
\hline 16 & 3 & & & & 3 \\
\hline 17 & 1 & & & & 1 \\
\hline 18 & 1 & & & & 1 \\
\hline 19 & 1 & & & & 1 \\
\hline 21 & 1 & & & & 1 \\
\hline 25 & 1 & & & & 1 \\
\hline 26 & 1 & & & & 1 \\
\hline 28 & 1 & & & & 1 \\
\hline 31 & 1 & & & & 1 \\
\hline 32 & 1 & & & & 1 \\
\hline
\end{tabular}




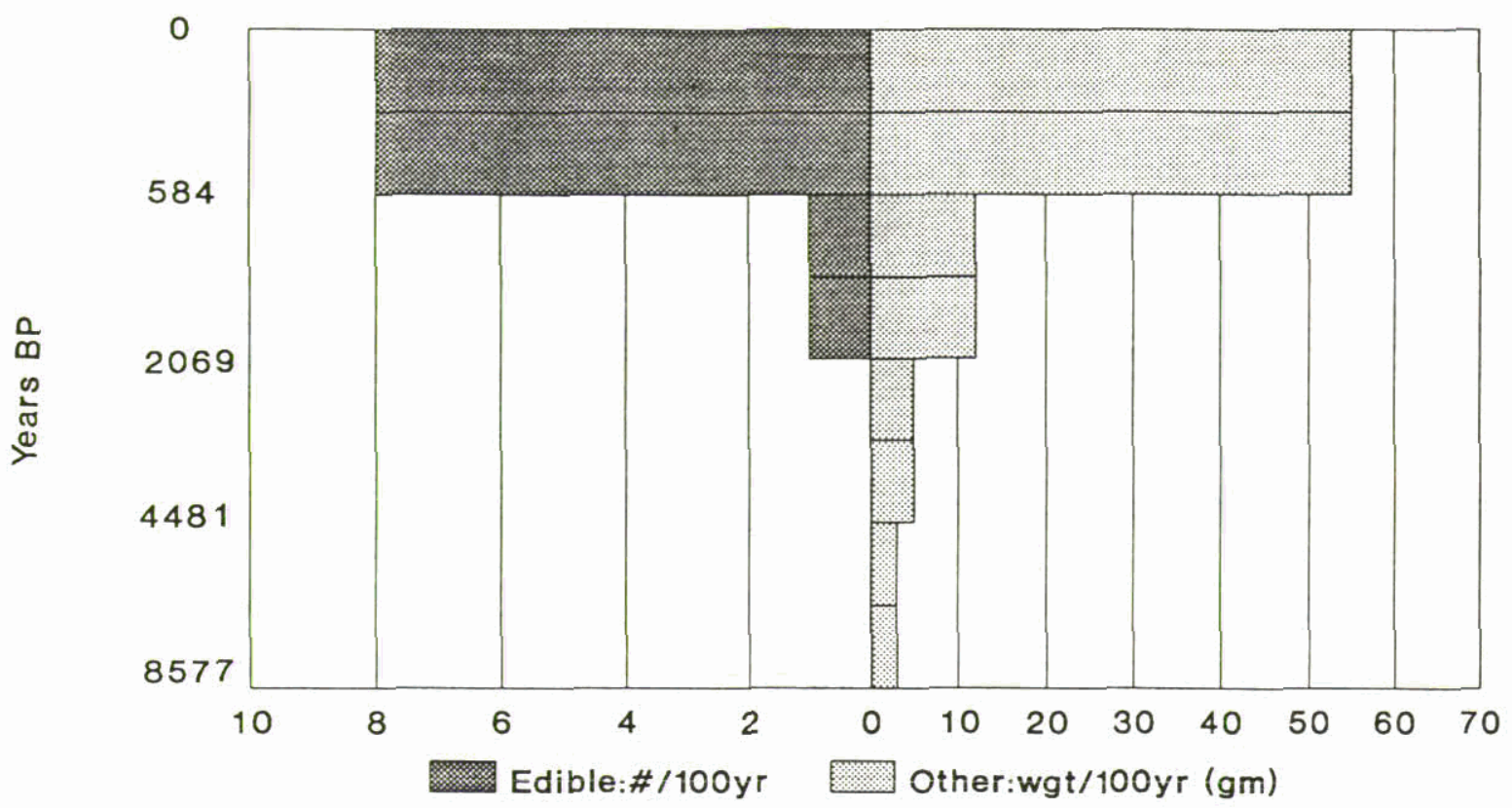

Figure 9. MNI of edible plant species per 100 years and weight (gm) per 100 years all other plant material.

\section{ANALYSIS: STONE ARTEFACTS}

Most of the stone raw material consists of an homogeneous finegrained volcanic chert, the most probable source of which is a large quarry on South Molle Island. The historically-reported use of this island as an artefact quarry plus reports that Aborigines travelled from Molle Island to Hook Island (Dalrymple 1860, Lamond 1960) lends support to this contention. Chert from this source comprised 928 of the stone artefact assemblage. The remainder was made from various highlysiliceous stone of volcanic origin (Figure 10A).

Eight percent of the stone artefacts were flaked pieces (flaking debris not possessing formal attributes of flakes such as platform, ring crack, etc. - see Hiscock 1988), 348 were flakes and 568 were broken flakes (Figure $10 B \&$ \& $10 \mathrm{C}$ ). Only 1.68 of flakes or broken flakes had evidence of retouch and there were no cores (Figure 10C). The stone artefacts had an overall average weight of only $0.55 \mathrm{~g}$, with an average weight in SU1 of $0.70 \mathrm{~g}$, in sU2 of $0.26 \mathrm{~g}$, in sU3 of $0.45 \mathrm{~g}$ and sU4, of $0.02 \mathrm{~g}$. Overall, the stages of decortication were 1.48 primary, $13 \%$ secondary and $83 \%$ tertiary. All but two of the primary and secondary artefacts were in su3 (Figure 10D).

Rates of artefact discard were greatest in sU3, with 6 per 100 years compared to a maximum of 1.28 per 100 years in the later units. Greater percentages of platform preparation in the form of overhang removal and platform faceting was also found in SU3 (Figure 1OE).

Red ochre in the form of small, rounded pellets was found in all excavation units dating to after 550 BP. The colour of the ochre visually resembles that used in the Nara Inlet art sites, although no faceted edges or abrasive use wear patterns which might more conclusively link the ochre to the art were observed (Figure 10F). More detailed petrological and geological analysis to determine both the source of the ochre and its association with the art is a consideration for the future. 
A

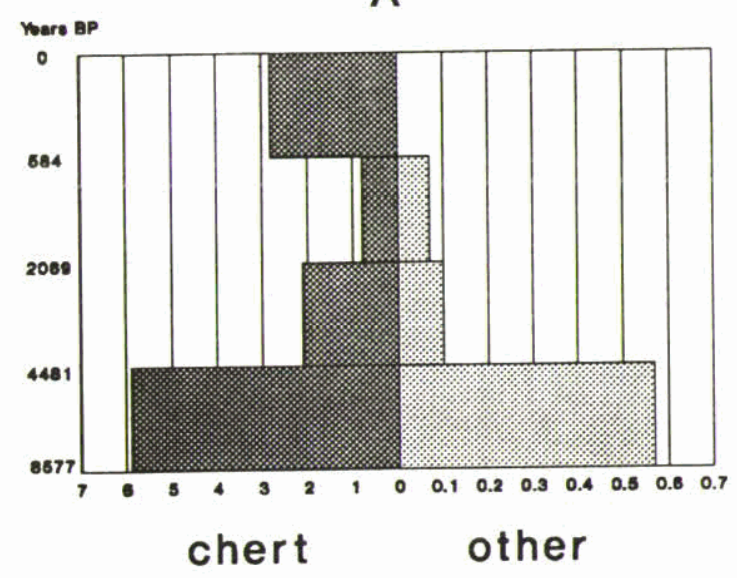

C

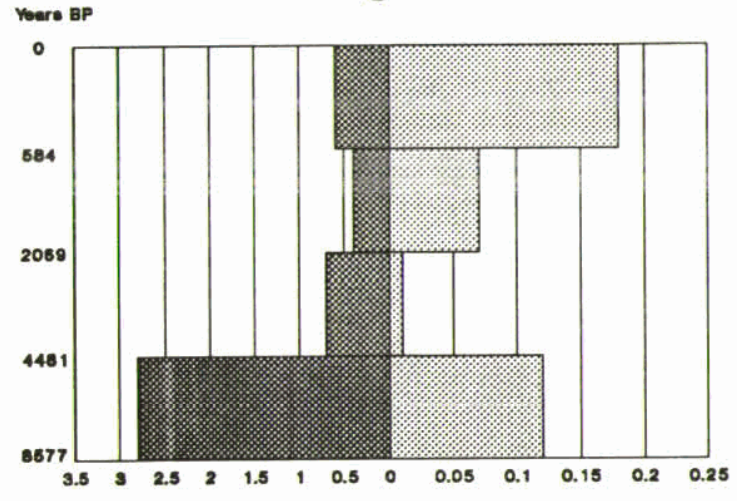

flakes retouch flakes
B

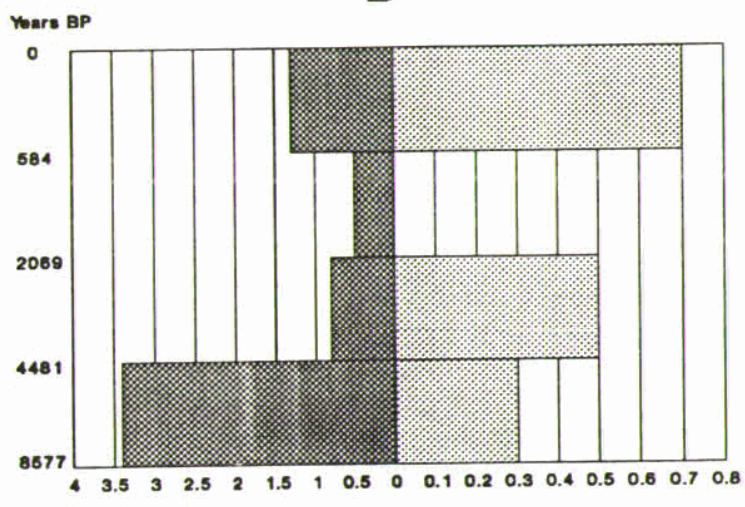

broken flakes Flaked pieces

D

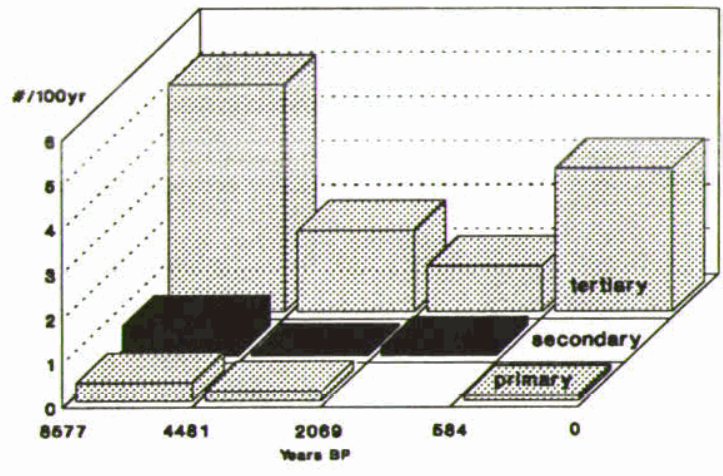

decortication

$\mathrm{F}$

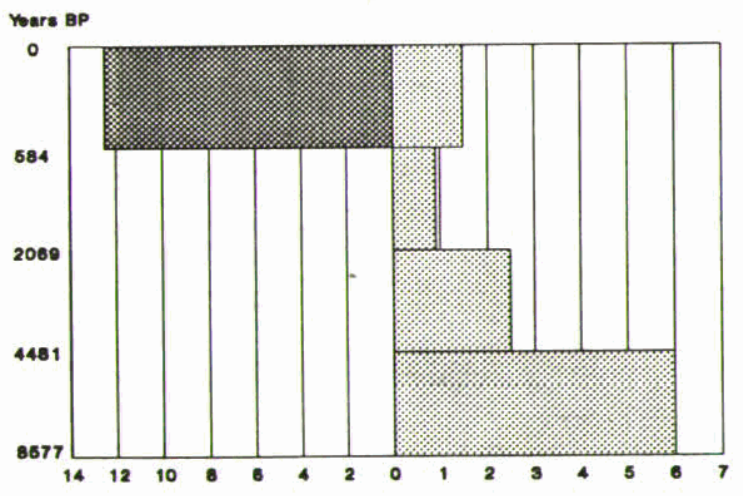

ochre stone artefacts

Figure 10. Discard of stone artefacts (number per 100 years) of:

A.platform facetting and overhang removal,

B.Raw material types, chert and other,

C.stages of decortication, primary secondary and tertiary,

D.ochre and total discard of stone artefacts,

B.flakes and retouched flakes,

F.broken flakes and flaked pieces. 
The significant decrease in discard rates of stone artefacts in the upper phase of the site coincides with the appearance of a number of non-lithic artefacts. These consisted of two rectangular pieces of cut and ground turtle shell, a wooden bi-point, two shell tools (scrapers), a shell with a triangular piece cut from it, two bone points made from the proximal fibula of small macropod, and pieces of netting (Table 5). These artefacts are illustrated and described in detail elsewhere (Barker 1990 in press).

Table 5. Non stone artefacts, number per XU for Nara Inlet 1.

\begin{tabular}{|c|c|c|c|c|c|c|}
\hline \multirow[t]{2}{*}{$X U$} & \multicolumn{5}{|c|}{ ARTEFACTS } & \multirow[t]{2}{*}{ TOTAL } \\
\hline & $\begin{array}{l}\text { Ground \& cut } \\
\text { turtle shell }\end{array}$ & Netting & $\begin{array}{l}\text { Wooden } \\
\text { point }\end{array}$ & $\begin{array}{c}\text { Shell } \\
\text { artefacts }\end{array}$ & $\begin{array}{l}\text { Bone } \\
\text { point }\end{array}$ & \\
\hline 1 & & 1 & & & & 1 \\
\hline 2 & 1 & & & & & 1 \\
\hline 16 & & & 1 & & & 1 \\
\hline 17 & & & & 1 & & 1 \\
\hline 19 & & & & & 1 & 1 \\
\hline 20 & 1 & & & & & 1 \\
\hline 23 & & & & 1 & & 1 \\
\hline 27 & & & & 1 & & 1 \\
\hline 28 & & & & & 1 & 1 \\
\hline TOTAL & 2 & 1 & 1 & 3 & 2 & 9 \\
\hline
\end{tabular}

\section{DISCUSSION}

Results of this excavation reveal that marine resources were exploited at Nara Inlet 1 from the time of its initial occupation sometime prior to 8577 BP. It is probable that an already marineadapted people began using the site because it was only at this time that it was close to the coast. It would appear that they reacted to the ever-encroaching seas by following the changing coastline. People using Nara Inlet 1 at this time were targeting a range of coastal fringe and mangrove littoral resources, the make-up of which remained largely unchanged throughout the entire period of the Holocene marine transgression. These species included the mud crab scylla serrata, and mud-dwelling bivalve species Isognomon ephippium which establishes the continued presence and use of mangrove ecosystems in the region throughout the Holocene (for a discussion on the viability and resilience of marine resources in the face of sea level rises see Woodroffe 1988; Barker 1990, in press).

The data from this site have revealed a sequence from which three major changes are inferred. The first, represented by Stratigraphic unit 3 , occurs when the site is initially occupied sometime prior to 8577 BP. The second change is represented by stratigraphic Unit 2 and falling somewhere between 4481 BP (XU35) and 2069 BP (XU28). I suggest that the date may be about 2700 BP, as excavation of a similar rockshelter on nearby Whitsunday Island, featuring all the elements of the later stratigraphic units found in Nara Inlet 1, has a basal date of this age. The third change occurs at the top of Stratigraphic Unit 2 at about 584 $B P$, and includes all of Stratigraphic Unit 1. 
From at least 8577 BP to some time between 4481 BP and 2069 BP, the sequence is characterised by fairly low densities of cultural material with average overall rates of sedimentation of only $0.009 \mathrm{~cm} / 100 \mathrm{yr}$. (Figure 11). I infer this fact to represent a fairly low level of visitation. Slightly higher rates of discard of terrestrial fauna, a fairly consistent discard pattern of fish remains and a much greater discard rate of stone artefacts contrasts with the much lower discard rates of shell and the absence of edible plant foods in this period (Figures 9, $10 \& 12$ ). I infer from this evidence that people were more terrestrially orientated and were exploiting both coastal and hinterland food resources. The diminished nature of remains deposited in this period may indicate infrequent small scale visitation where hunting activities took precedent over gathering.

Stratigraphic Unit 2, probably dating to (or between) approximately 2700-3000 BP, is characterised by significantly increased amounts of cultural material (average deposition rates of $2.5 \mathrm{~cm} / 100 \mathrm{yr}$ ) and a greater diversity of resources. Charcoal, shell, fish, and crab all show increases in discard (Figures $11,12 \& 13$ ). The seeds of the summerfruiting Burdekin Plum appear for the first time in this unit, as do the bivalves Pinctada sp. and Asaphis deflorata. The presence of large, deep-sea marine reptiles and mammals in the form of Chelonia mydas and Cetacea respectively, also reflects the expansion of marine resource procurement in this unit. The decrease in the discard rate of stone artefacts in this unit may be indicative of a tool kit becoming more adapted to an increased marine exploitation. This notion is reinforced by the sudden appearance of a significant number of non-lithic artefacts made either from marine animals or historically-documented as having been used for their procurement. These include cut and ground pieces of turtle shell which may have been fish hook blanks, shell tools (scrapers) including one which has had a rectangle cut from it, a bone point, and a wooden bi-point, described by Roth, (1907) and Lumholtz (1889) as distinctive in the Whitsunday area and used as the barb of a dugong harpoon. I infer that this unit reflects both a more intensive use of the site and a more broadly-based marine resource procurement strategy. In short, the people on Hook Island had by this time become marine specialists to a greater degree than previously.

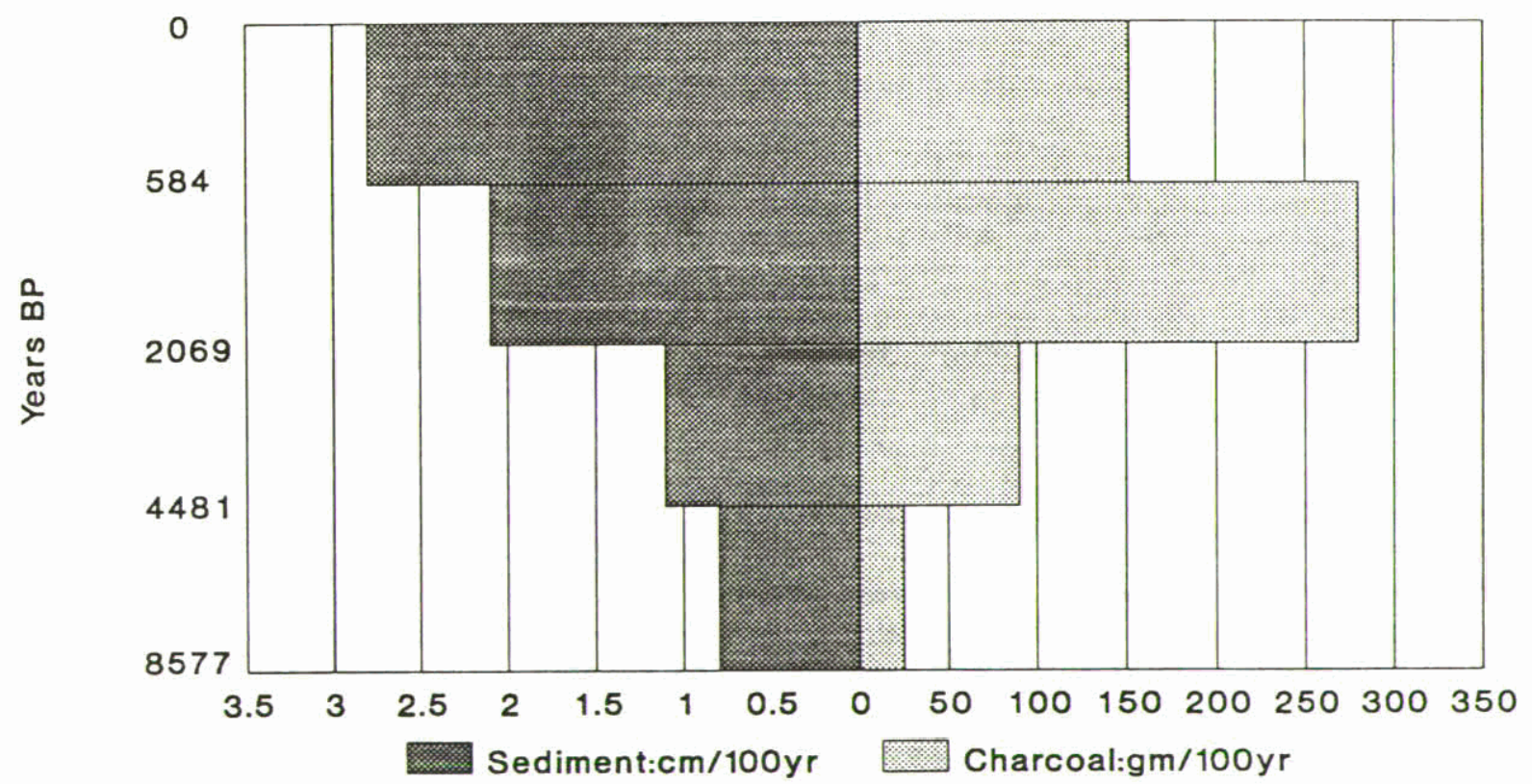

Figure 11. Total rates of sedimentation over time $(\mathrm{cm} / 100$ years) and charcoal (gm/100 years). 


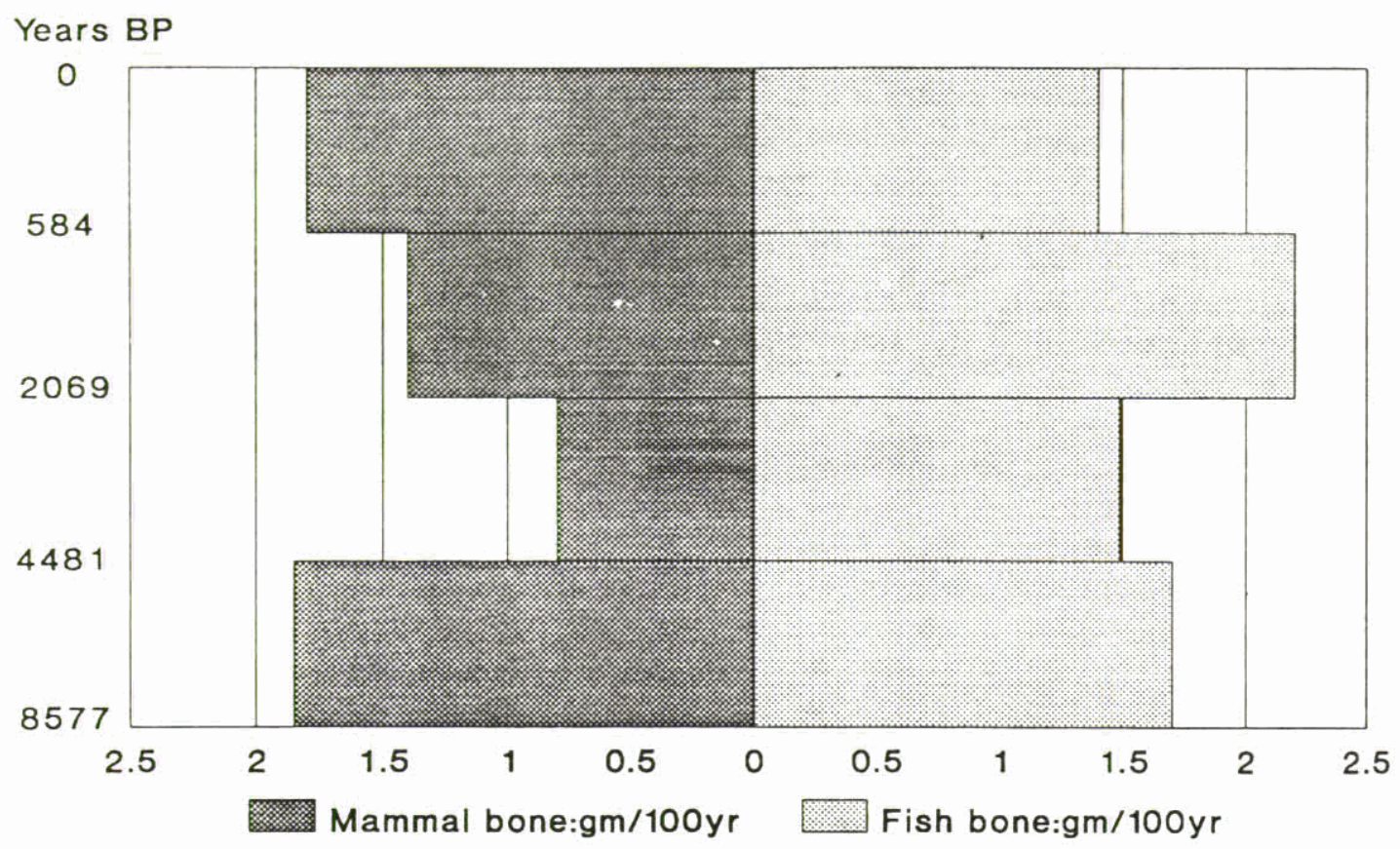

Figure 12. Discard of terrestrial fauna bone (gm/100 years) and fish bone $(\mathrm{gm} / 100$ years $)$.

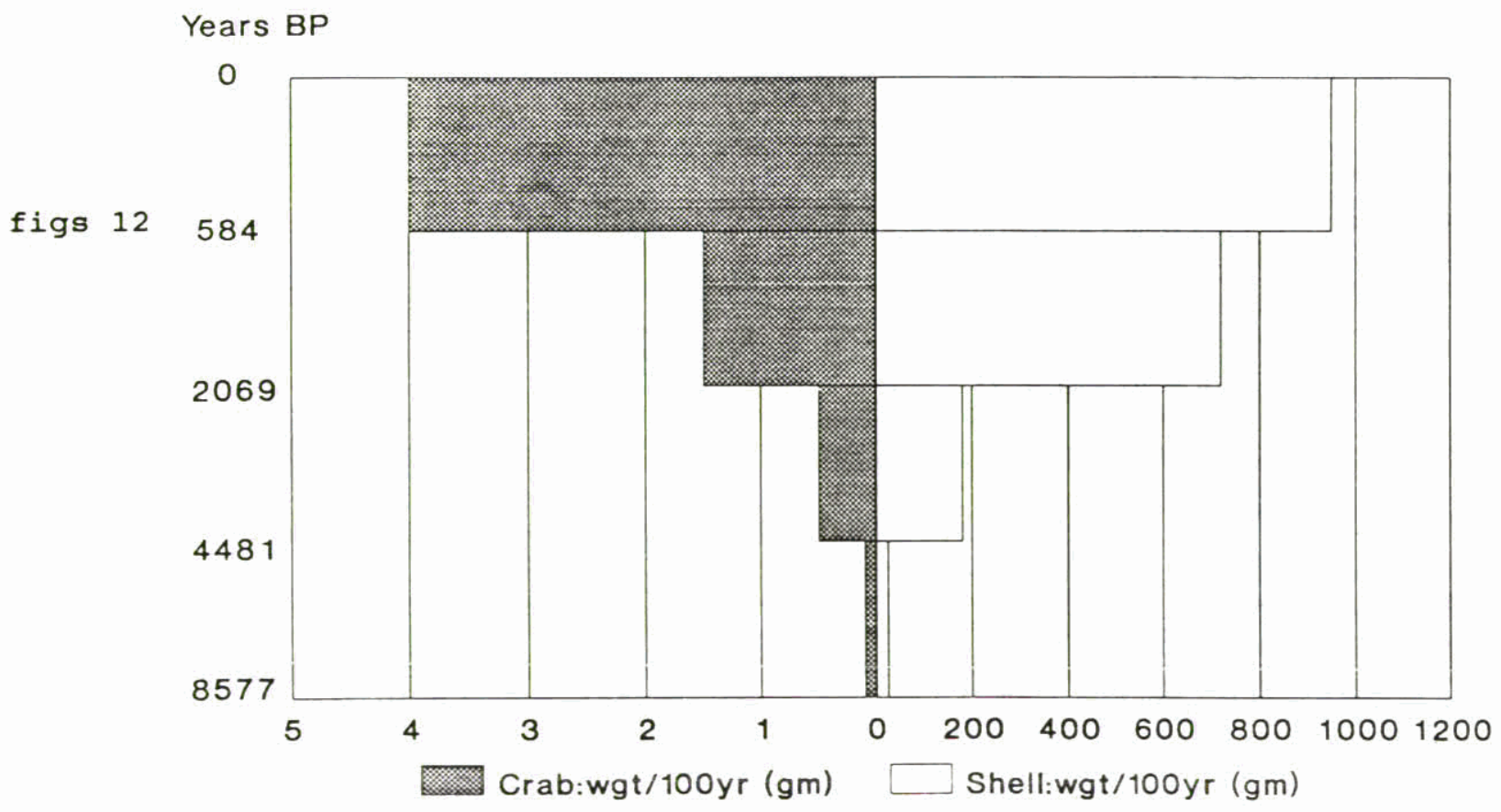

Figure 13. Total weight $(g \mathrm{~m})$ of crab species per 100 years and total weight $(\mathrm{gm})$ of shell per 100 years. 
For the period after 584 BP I infer a continuation of this trend towards a greater degree of specialization. Discard rates for nearly all resources show increases and there are significant additions at this time, namely cycad nuts and mangrove pods, both of which are edible plants which require extensive processing in the form of leaching and grinding before consumption. Ochre also appears after 500 BP and can reasonably be associated with the distinctive art found in Nara Inlet. Thus, this phase is seen as reflecting both a further expansion of the resource base and an increase in cultural activity at the site; it may well represent the dynamic system described historically.

\section{CONCLUSION}

The evidence gained from Nara Inlet 1 shows that people were exploiting marine resources from its initial occupation sometime prior to ' 8577 BP. By at least 6500 BP, "Hook Peninsula" had become a series of islands. Occupation continued largely unchanged, with the marine transgression having little or no apparent effect on the availability of marine resources. At around 2500 BP, there was a significant decrease in the discard rate of stone artefacts, and changes in patterns of manufacture suggest either differential access to the quarry site on South Molle Island or a change in technological emphasis. At the same time there are significantly increased rates of discard of other cultural material such as charcoal and shell, as well as apparent technological change. A wide variety of artefacts manufactured from bone, wood, shell, and turtle shell as well as stone was introduced at this time. In general, this change is inferred to represent a broadening of the resource base, a greater degree of marine resource specialization and an increase in human activity at the site.

Clearly, the major change at Nara Inlet 1 occurred in the late Holocene, which corresponds with the coastal and island occupation of other sites documented along the east coast of Australia (Campbel1 1982, Beaton 1985, Hall 1984). There is no evidence in this site that the marine transgression affected the availability of resources or people's access to them. Further field work and the analysis of recently excavated material should provide further clues as to the causes of this change.

\section{ACKNOWLEDGMENTS}

Many thanks to Harry Lourandos, Jay Hall, Bruno David, Ian McNiven, Su Davies and Kathy Frankland for comments and discussions relating to this paper. I am most grateful to Mike Rowland for making available details of his initial research and for providing the opportunity to work in the Cumberland Group. Thanks also to the Queensland National Parks and Wildife service for being interested and for their assistance.

\section{REFERENCES CITED}

Barker, B. 1988 Nara Inlet 1: Preliminary research from the 1988 field season. Unpublished report, Department of Anthropology and Sociology, University of Queensland. 
Barker, B. 1990 occupation. time lag. and the trauma of marine transgression; a reappraisal of coastal occupation models. Archaeology in Oceania (In press).

Beaglehole, E. 1955 .The Journals of Captain James Cook on His Voyage of Discovery. Vol.1 Cambridge University Press: Hakluyt Society Cambridge. $\because \quad$ : . . . . .

Beaton, J.M. 1985 Evidence of a coastal occupation time-lag at Princess Charlotte Bay (North Queensland) and.implications for coastal colonisation and population growth theories for Aboriginal Australia. Archaeology in Oceania 20 (1):1-20.

Border, A. 1985 Unchartered Waters: Hunter-gatherer specialisation on the Central Queensland Coast. Unpublished B.A. Honours Thesis, University of New England, Armidale NSW.

Campbell, J.B. 1982 Automatic sea-food retrieval systems: evidence from Hinchinbrook Island and its implications. In s. Bowdler (ed) Coastal Archaeology in Eastern Australia. Australian National University, Press: Cąnberra.

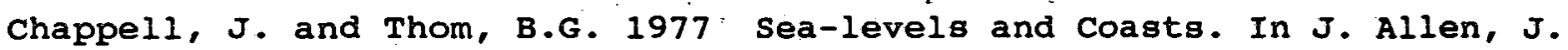
Golson and R. Jones (eds) Sunda and Sahul. Academic Press: London.

Coppinger, R.W. $1883^{\circ}$ Cruige of the "Alert" 1878-82. W. Swan Sonnenschein and Co. London.

Curr, E.M. 1887 The Australian Race vol.3. John Ferres Government Printer. Melbourne.

Cribb, A.B. and J.W. 1986 wild food in Australia. Collins. Sydney.

Dalrymple;, G.E. 1860 Report of the Proceedings of the Queensland Government schooner, "spitfire" 'in search of the mouth of River Burdekin. T.P. Pugh, Brisbane.

Finders, M. 1814 A voyage-to Terra Australis vol 2 . Bulmer and Co. London.

Flood, P..G. $1983_{i}$ Holocene sea-level data from the Great Barrier. Reef and southeastern, ${ }^{\prime}$ Queensland - a. review. In D. Hopley (ed), Augtralian Sea-Levels in the Last .15000 Years: A review. Occasional Paper 3, Monograph Series, Geography Department, Jámes Cook University.

Gill, E.D. 1983 Australian sea levels in the last 15000 years -Victoria, S.E. Australia.. In D. Hopley.-(ed), i Australian : Sealevels in the last 15000 years: A Review. Occasional Paper 3. , :-Monograph Series, Geography Department-James Cook University.

Gil1, E.D. \& Hopley, D. 1972 Holocene sea levels in eastern Australia. Journal of Tropical Geology, 12: 223-233.

Grant, E.M. 1985 Guide to Fishes. Department of Harbours and Marine, Brisbane. 
Gregory, E. 1896 Narrative of James.Murrils (Jemmy Morrill seventeen years exile among the wild blacks of north Queensland and his life and shipwreck and terrible adventures among savage tribes; their manners, customs languages, and superstitions;

\% * also Murrils rescue and return to civilisation. Brisbane. I?.

Haddon, A.C. 1913 The outrigger canoes of Torres strait and North Queensland.

In Quiggen, E.C., Essays and studies: presented to Wm. Ridgeway, pp. 609: 34. Cambridge" University "Press .

Haddon, A.C. and Hornell, J. 1937 Canoes of Oceania. Vol 2. Honolulu, Bernice P. Bishop Museum (Speciäl Publication No. 28):

Hall, H.J. 1984 Exploratory excavation at Toulkerrie Midden:(IB:B 175), - Moreton Island, S.E. Queensland. Queensland Archaeological - Research. 1:61-84.+

Hiscock, P. 1988 Prehistoric settlement pätterns and artefact manufacture at Lawn, Hill, Northwest Queensland: Unpublished Ph.D. thesis. University of Queensland.

Hopley, D. 1974 Investigations of sea level changes along the coast of the Great Barrier Reef. Proceedings of the second International Coral Reef Symposium, 2: 551-562.

Hopley, D. 1975 Contrasting evidence för Holócene sea levels with special reference to the Bowen-Whitsunday area of queensland. 2. - In Douglas"et al, Geographical Essays in Honour of Gilbert $J$. Butland, pp 51-84 Department of Geography, University of New England, Armidale.

Hopley, D. 1983 Australian sea-levels in the last 15000 years: a *. review.: Occasional Paper 3. Monograph series, Geography Depártment, James Cook University:

Jack, R.L. 1922 Northmost Australia: three centuries of exploration, discovery and adventure in and around Cape York Peningula. 2 vols, Simpkin, London.

James, G. nó date How Bowen was discovered: the cruiserof the santa. Barbara; 9 tons, in search of a northern port in the year 1859. Boweñ. Independent Print, Bowen:

4.

King, P.P." 1827 Narrative of a Survey of the" Inter-tropical and Western Coasts of Australia. Vol 1. John Murray, London.

- - - :

Lamond, +H.G. 1960. An Island Tribe. North queensland Monthly $7(5): 35,40$.

Lourandos, H. 1980 .. Change or stability? : hydraulics, hunter-gatherers and population in temperate Australia. World Archaeology $2(3):$

randos, H. 1983 Intensification: a late Pleistocene-Holocene Louraños, H. 1983 Intensification: a late pleistocene-Holocene
archaeological sequence from southwestern victoria. - Archaeology in Oceania 18 (20):81-94.

Lumholtz, C. 1889 Among Cannibals. A.N.U Press 1980, Canberra. 
McCarthy, F.D. 1939 Trade in Aboriginal Australia, and trade relationships with Torres strait, New Guinea and Malaya. Oceania $9(4): 405-38$.

Moore, D.R. 1979 . Islanders and Aborigines at Cape York. An ethnographic reconstruction based on the 1848-1850 'Rattlesnake' Journals of O.W: Brierly and information he obtained from Barbara - Thompson. Australian Institute of Aboriginal studies, Canberra.

Morwood, M.J. 1982 The saga of wild duck: A recipe for cultural resource mismanagement. In $S$. Bowdler (ed). Coastal Archaeology in Eastern Australia. pp. 108-113. Canberra: Australian National University, Department of Prehistory, Research School of Pacific studies.

Neal, R. 1985 Archaeological reconnaissance of the Port Clinton area, Shoalwater Bay, central queensland. Report on file, University of Queensland Archaeological services Unit (UQASU).

Neumann, A.C. 1972 Quaternary sea level history of Bermuda and the Bahamas, Amexican Quaternary Association second National Conference Abstract. 41-44.

Paine, A.G.L. 1972 Proserpine, Qld. 1:250,000 Geological series Explanatory Notes. Canberra: Australian Government Publighing service.

Roth, W.E. 1907 The Queengland Aborigines. North Queensland Ethnography Vol 1, 11, 111. Bulletins 9-18, Records of the Australian Museum, Sydney 1907-1910.

Rowland, M.J. 1980 The Keppel Islands - preliminary invegtigation. Augtralian Archaeology 11:1-17.

Rowland, M.J. 1981 Radio carbon dates for a shell fishhook and disc from Mazie Bay, North Keppel Island. Australian Archaeology $12: 63-69$.

Rowland, M.J. 1986 The Whitsunday Islands: Initial Historical and Archaeological observations and Implications for Future Research. Queensland Archaeological Research. 3:72-87.

Stokes, J.I. 1846 Discoveries in Australia; with an account of the coasts and rivers explored during the voyage of H.M.S. Beagle. 2 vols. London.

Stuiver, M. and P.J. Reimer 1986 A computer program for radiocarbon age calibration. Radiocarbon 28:1022-1030.

Thom, B.G. and Chappell, J. 1975 Holocene sea-levels relative to Australia. Search 6:90-93.

Thom, B.G. 1984 Geomorphic research on the coast of Australia: a preview. In B.G. Thom (ed) Coastal Geomorphology in Australia. Academic Press. Sydney.

Tindale, N. 1974 Aboriginal Tribes of Australia. University of California Press. Berkeley. 
Walsh; G.I. 1985 Archaeological Significance of Hook Island. Unpublished Report to National Parks and Wildlife service, Brisbane.

Woodroffe, C. 1988 Changing Mangrove and Wetland Habitats over the last 8000 years, Northern Australia and Southeast Asia. In WadeMarshall and Loveday; (eds) Floodplaing Research. Australian National University, North Australia Research Unit, Darwin. 